\title{
ELLIPSIS TYPES IN STEPHENIE MEYER'S “THE SHORT SECOND LIFE OF BREE TANNER” USING A SYNTACTIC ANALYSIS
}

\author{
Andi masniati \\ Institute Agama Islam Negeri Ambon \\ masniatiandi@gmail.com \\ Azwan \\ Universitas Iqra Buru \\ azwanuniqbu@gmail.com
}

\begin{abstract}
Ellipsis is an omitting part of the sentence that may occur in the English novel. Some authors write a novel tend to use ellipsis in their work. Learners who read English novel are likely to find the author's writing style which study is aimed to explain the types of the elliptical sentence used by the author in the novel The Short Second Life of Bree Tanner. This research applied a qualitative method and employed a source of data from Stephenie Meyer's Novel and some references to support this study. A further technique of analyzing data in this research is always linked to the theory and methods based on Syntactic Analysis. Subsequently, this research uses the syntactic analysis form, Noam Chomsky. As a result, the researcher found that there are three types of elliptical sentence occurred in the novel. The types of elliptical sentence are a nominal ellipsis, verbal ellipsis, and clausal ellipsis. Therefore, based on the research findings, the researcher concludes that the types of ellipsis the author used in her novel based on the evidence are verbal ellipsis, nominal ellipsis, and clausal ellipsis. As a suggestion, it is essential to learn light on the readers or writers' ability to employ ellipsis types in their work as it is necessary in more economizing and conceiving sentence.
\end{abstract}

Keywords: Ellipsis, nominal, verbal, clausal, syntactic analysis

\section{A. INTRODUCTION}

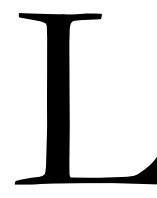

anguage is used by people to communicate with each other in every social activity. By using language, people not only can conceal and reveal their characters, identity but also

can get knowledge and understand about the things around them. It is in line that language is most commonly defined as a form of communication that is no stereotyped and nonfinite; it is learned and created (Crane et al., 1981). Meaning generally that language is unlimited and speakers of a language can produce and interpret an unlimited number of utterances that they have never heard before.

There are some languages in the world that have their systems. One of them used in most country as an international language is English. English is the international language becomes more advanced in many countries. Therefore, English has its place in our life as an important language.

Learning English as a foreign language is not an easy subject. It has difficult rules in its system. Sometimes, in using this language, providing word or phrase to be substituted or we can 
simply omit it, so we successfully reconstruct the omitting words. As a result, we often find the omission in a certain part of the expression that should be in the sentence in which the same words are not repeated. Therefore, ellipsis becomes one of elements which should be identified to compose the writer adequate piece of writing. Ellipsis is omitting part of the sentence on the assumption that an earlier sentence or the context will make the meaning clear (Cook, 1982). Consequently, ellipsis is done to avoid repetition and make a sentence more concisely. Although one or more words are omitted, the meaning of the sentence is not different from the complete or unomitted sentence of written text. Written text is related to the use of language as a means of communication in which we can find in the novel. A novel uses dialogue rather than explanation and it is easier for researcher to see and analyze the ellipsis in utterances.

This paper settled an objective to answer the following research question: what types of elliptical sentence are used by the author? This study is expected to fill in the theoretical gap that exist in English writing style; while practically, it hopefully can be one of the references for other researchers who are interested in this discipline and for authors who are still struggling writing their work.

\section{B. LITERARY REVIEW}

There are three categories in the classification of ellipsis they are Nominal, Verbal, and Clausal Ellipsis. (McCarthy, 1991; Halliday, Hassan, 1976).

Nominal ellipsis is the common noun may be omitted, and the function of the head taken on by one of these other elements, the elements that occur in a nominal ellipsis are the deictic, the numerative, the epithet, the classifier and the qualifier (Halliday, Hassan, 1975).

The Deictic is mostly of the class of determiner, demonstrative, possessive, and indefinite determiner from a network of systematically related categories. Deictic also includes the articles (Halliday, 1976). For example "Here the other guinea-pig cheered, and was suppressed." The is an article. It is deictic. Other is an adjective; it is posted deictic. The words the and other in the second clause are omitted.

Within the deictic proper, the major distinction and that this is most relevant to ellipsis is into specific deictic and non-specific deictic. The speech of deictic consists of possessive, demonstrative and the. Possessives include both nominal (my father's, Chandra's, etc.) and pronominal (my, your, etc.). The latter has a special from when functioning as head: mine, ours, yours, his, her, theirs, whose, and (rarely) it's. For example "Just ask Jeannie how to polish the 


\section{Andi masniati, Azwan, Ellipsis Types in Stephenie...}

brassware. Hers sparkles". In this sentence, hers occur as the head. There is a double cohesive tie, where hers presupposed both a person as possessive and a thing possessed, the former by reference (ber), the latter by an ellipsis (the possessed).

The Demonstrative (This, That, These, Those, Which) All Occur Elliptically. For example "Take the pills three times daily. And you would better have some more of those too". The demonstrative those here function as head: where those elliptic for those pills. The words the do not operate elliptically since its function is to signal that the thing designated is fully defined. The is required by another item with it, as in the two, the small (one), the one that got away.

The non-specific deictic is each, every, any, either, no, neither, a, and some, as well as, all and both. They occur as head of a nominal ellipse except every. However, $a$ and no have to be symbolized by the forms one and none correspondingly. For example "I won't introduce the pudding, please. May I give you some?" Some in the second clause occur as the head. It is elliptically for some pudding. Specific deictic and non-specific deictic may be combined only through the use of a partitive qualifier. For example "each of my children" "any of the answer."

The pre-deictic are both and all which can be determined as in all our yesterdays and both these gates. Both and all refer back to the plural nominal group. Both presuppose plural noun group, which has a sense of "two" and all to presuppose for more than noun group.

The post-deictic are adjectives, including other, some, different, identical, usual, regular, certain, odd, famous, well-known, typical, and obvious. They are combined with the, $a$, or another determiner. The post-deictic other combines either with specific deictic (the other, another, etc.) and when it's used as the head, it has a special plural from other. For example "I have used up these yellow folders you gave me, can I use the other?" The other in this sentence does not mean the other three. With a specific deictic, other refers to the last remaining member of yellow folders and presupposes that all others must have been specified.

Verbal ellipsis is within the verbal group. The elliptic verbal group presupposes one or more words from the previous verbal group. We defined as a verbal group when the structure does not entirely express its systemic features, all the choices that are being made within the verbal group system. For example A: "Have you been swimming?" B: "Yes, I have." The verbal group in the answer, Yes, I have is the instance of the verbal ellipsis. It can be said to stand for have been swimming, and there is no possibility of filling out with other items. It could be interpreted only as 
Volume 5, Number 01, June 2019

I have been swimming or replaced by I have been swimming. The full form and the elliptical one are both possible.

There are two types of verbal ellipsis (Halliday, Hassan, 1976). Lexical ellipsis is the type of ellipsis in which the lexical verb is missing form the verbal group. It is the lexical verb that $s$ always omitted. "Lexical ellipsis is ellipsis from the right; it always involves omission of the last word, which is the lexical verb, and many extend 'leftward,' to leave only the first word to be intact. (Halliday, Hassan, 1976)." For example A: "Should anyone have been come" The answer could be given as B: "Katty should have been." "Katty should have, or simply." "Katty should."

A very clear example of lexical ellipsis is provided by question tags. All question tags have maximum lexical ellipsis and presuppose all the features of the relevant verbal group. For example "John couldn't have been going to be consulted, could he?" The place of lexical ellipsis in the sentence is after the subject at the end of the sentence. The word omitted is having been going to be consulted.

Operator ellipsis is another type of verbal ellipsis 'from the left.' We shall refer to this as operator ellipses. The initial element in the verbal group is omitted, and the following elements may be omitted from the clause. It must, therefore, be presupposed. For example A: "What have you been doing?" B: "Sleeping." The operator ellipsis is I have been, and sleeping is a lexical verb. In this example, the words I have been are omitted.

Clausal ellipsis considered as the expression of the various speech functions, such as statement, question, response, etc., has a two-part structure consisting of modal element and prepositional element. For example "Jane is going to buy a new car." This sentence has a two-part structure which consists of modal and prepositional elements. In this sentence, the modal element is Jane is, and the prepositional element is going to buy a new car.

The modal element which includes the speech function of the clause, consist in turn of the subject plus the finite element in the verbal group. For example A: "What were they doing?" B: "Holding hands." The modal element is omitted in B; the subject is they and the finite is were. Modal ellipsis is the realization of speech function and expressed by the modal element. Modal ellipsis occurs in response to a WH-Question. For example A: "What is she doing?" B: "Playing some games."

The prepositional element consists of residue the remainder of the verbal group and any complements or adjuncts. It is also found in response to WH-Question where the unknown 


\section{Andi masniati, Azwan, Ellipsis Types in Stephenie...}

element happens to be the subject. For example, A: "Who thought him to be a teacher?" B: "His father did." In this example, the expression of B is elliptical. Here the prepositional element taught him to be a teacher has been omitted. So taught him to be a teacher is the complement of the modal element (his father did).

\section{RESEARCH METHOD}

This study employed a qualitative method. It aims to analyze the types of elliptical sentences occur in the novel which is relevant to this research.

The researcher used note-taking as an instrument of the research in collecting data. After reading the novel The Short Second Life of Bree Tanner and other references, the researcher makes some notes to classify the important unit.

The procedures of collecting data used by the researcher are 1) the researcher first reads the novel carefully. Through this way, the researcher finds and decides elliptical sentence in the novel. In this case, the researcher notes some sentences considered which contain ellipsis. 2) The researcher states the information, which donates about the ellipsis. 3) The researcher collects and reads some related literature to support the object analyzed in this research.

In analyzing data, the researcher used one of the technique is a syntactic approach to analyze the novel "The Short Second Life of Bree Tanne" by Stephenie Meyer based on Chomsky's theory. Syntactic is the study of the principles and processes by which sentences are constructed in particular languages (Chomsky 1971). The syntactic analysis will be used to analyze a literary work by finding some sentences contraction in the text of the novel. Syntactic findings are how a generative grammar is organized by using a heuristic procedure that can be identified as a simple following sentence A: "Sincerity may frighten the boy" B: "Sincerity may." In this case, the second clause can be interpreted as sincerity may frighten the boy.

The string is a sentence (S), frighten the boy is a Verb Phrase (VP) consists of the Verb (V) frighten and the Noun Phrase (NP) the boy, sincerity is also an NP, the NP the boy consists of the Determiner (Det) the, followed by a Noun (N) boy, the NP sincerity consists of just a Noun, the is an Article (Art), may is a Verbal Auxiliary (Aux) and, furthermore a Modal (M).

The Noun Phrase (sincerity) functions as the subject of the sentence, whereas the Verb Phrase (frighten the boy) functions as the predicate of this sentence, the Noun Phrase (the boy) functions as the object of the Verb Phrase, and the Verb (frighten) as its Main Verb, the 
Volume 5, Number 01, June 2019

grammatical relation Subject-Verb holds of the pair (sincerity, frighten), and the grammatical relation Verb-Object holds of the pair (frighten, the boy).

From the dialogue, we can see there is a verbal ellipsis. The omitted items occur in the second clause sincerity. The Verb Phrase frighten the boy omitted in the second clause. In this case, the unellipted form of the second clause is sincerity may frighten the boy.

\section{FINDING AND DISCUSSION}

The results of the types of elliptical sentence in the novel are provided below:

\section{Nominal ellipsis}

Diego: "Better than Freaky Fred's backside."

Bree: "I can't argue with that."

Analysis Bree's answer can be interpreted as I can't argue with Freaky Fred's backside.

The string is a sentence (S) argue with Freaky Fred's backside is a Verb Phrase (VP) consists of the Verb (V) argue as the Main Verb functions as a Predicate of the sentence and the Prepositional Phrase (PP) with Freaky Fred's backside functions as a Complement of the sentence, $I$ is also a Noun Phrase (NP) functions as Subject of the sentence and the Prepositional Phrase (PP) with Freaky Fred's backside consists of Preposition (with), followed by an NP Freaky Fred's backside, the NP I consists of just a Pronoun (I), can't is a Verbal Auxiliary (Aux) and, furthermore a Modal (M) and the grammatical relation Subject-Verb holds of the pair (I, argue) and the grammatical relation Verb-Complement holds of ( argue, with Freaky Fred’s backside).

From the dialogue, we can see the finding that there is a Nominal ellipsis. The omitted items occur in Bree's utterance I can't argue with that. The Prepositional Phrase with Freaky Fred's backside is omitted in Bree's utterance which they are Freaky Fred's as possessive and backside as noun. This proposition is supported by Yulianti (2009) that the omitted words in the nominal ellipsis are possessive and noun. In addition, Suratni (2006) also see that the use of nominal ellipsis in the dialogue is to fulfill the principle of economizing language and space ranting.

\section{Verbal ellipsis}

Bree: "doesn't it feel like whatever's coming ......"

Diego: “.... it does."

Analysis Diego's answers can be interpreted as it doesn't feel like whatever's coming. 


\section{Andi masniati, Azwan, Ellipsis Types in Stephenie...}

The String consists of two sentences structure (S), feel like is the first Verb Phrase (VP) consists of the Verb (V) feel as a Main Verb functions as a Predicate in the first sentence and the Preposition (Prep) like functions as a Complement in the first sentence, and coming is the second Verb Phrase (VP) consists of the Verb (V) coming as a Main Verb functions as a Predicate in the second sentence and it is also a Noun Phrase (NP) functions as a Subject of the sentence, the Noun Phrase (NP) it consists of just a Pronoun (Pron), don't and is are a Verbal Auxiliary (Aux) whatever is Conjunction and the grammatical relation Subject-Verb holds of the pair ((it, feel) and (it, coming)).

From the dialogue, we can see the next finding that there is a verbal ellipsis. The omitted items occur in Diego's utterance it does. The Verb Phrase not feel like is omitted in the second clause, and also the sentence whatever's coming is omitted in Diego's called lexical ellipsis. As proposed by Marcus (1982) that by examining a restricted corpus verbal ellipsis in the dialogue, it becomes evident that there is, in fact, verbal ellipsis usage with regard to this topic. It must be taken into consideration in teaching of verbal ellipsis in English to Indonesian student.

\section{Clausal ellipsis}

a. Jane: "She was in addition to the eighteen here?"

The Redhead: "Yes."

Analysis The redhead's answer can be interpreted as yes, she was in addition to the eighteen here.

The String is a sentence (S), was in addition to the eighteen is a Verb Phrase (VP) consists of the Verb (V) was as a Main Verb functions as a Predicate of the sentence and the Prepositional Phrase (PP) in addition to the eighteen functions as a Complement of the sentence, she is also a Noun Phrase (NP) functions as a Subject of the sentence, the Prepositional Phrase (PP) in addition to the eighteen consists of Preposition (in), followed by a NP addition; and Proposition (to), followed by a Noun Phrase (the eighteen), the NP she consists of just a Pronoun (we), here is an Adverb of Place and yes is an Adverb and the grammatical relation Subject-Verb holds of the pair (she, was) and the grammatical relation Verb-Complement holds of (was, in addition to the eighteen).

From the dialogue, we can see the last finding that there is a clausal ellipsis. The omitted items occur in the Redhead's utterance yes. The clause she was in addition to the eighteen here is omitted in the Redhead's utterance known as prepositional element. Priadi (2014) highlighted that clausal ellipsis mostly occurs in dialogues. When some elements in dialogue are repeated, they become unnecessary information that lead to redundancy. Therefore, they need to be omitted to achieve 
effective writing. Furthermore, Muhdar (2007), Hamzah (2015) also emphasized that clausal ellipsis occurs dominant in dialogue which plays important role in understanding the missing conversation.

\section{E. CONCLUSION}

The conclusion that can be drawn from the result above that the findings showed clausal ellipsis is the most dominant type among the two other ellipsis types, called nominal and verbal ellipsis which meant to make the conversation more concise without breaking the meaning and able to be conceived. In addition, these findings can lead the students to apply such kind of writing style so they can help them organize their writings. Furthermore, the most proficient writers appeared to undervalue their writing style.

\section{REFERENCES.}

Chomsky, Noam. (1965). The aspect of the Theory of syntax. Cambridge: The M.I.T. Press. (1971). Syntactic Structures. Paris: Mouton.

Cook, Guy. (1990). Discourse. Oxford: Oxford University Press.

Crane, L. Ben, et al. (1981). An Introduction to Linguistics. Canada: Little, Brown, and Company. Halliday, M.A.K and Hassan Ruqaiya. (1976). Cohesion in English. London: Longman Inc.

Hamzah. (2005). Skripsi. Ellipsis Analysis in "Look Back in Anger" by Jhon Osborn. Hasanuddin University. Makassar.

Harrison, Bemard. (1972). Meaning and Structure: An Essay in the Philosophy of Language. New York: The University of Sussex.

Hill, Archibald A. (1969). Linguistic Today. New York: Basic, Books, Inc.

Lappin, Shalom. (1996). The Interpretation of Ellipsis, ed. Shalom Lappin. Oxford: Blackwell. Leech, Geofrey, et al. (1975). A Communicative Grammar of English. London. Longman.

Marcus, Inge H.E. (1982). The Cohesive Relation of Verbal Ellipsis in English and Its counterparts in pourtugese. https://acervodigital.ufpr.br/bitstream/handle/1884/34843/d\%20\%20inge $\% 20$ hannelor $\underline{\mathrm{e} \% 20 \text { elfriede } \% 20 \text { marcus.pdf?sequence }=1 \text { \&isallowed }=\mathrm{y}}$

McCarthy, Michael. (1991). Discourse Analysis for Language Teachers. Cambridge: Cambridge University Press. 


\section{Andi masniati, Azwan, Ellipsis Types in Stephenie...}

Meyer Stephenie. (2010). The Short Second Life of Bree Tanner. New York: Little, Brown, and Company.

Muhdar. (2007). Skripsi. The Analysis of Ellipsis in Ernest Heming Way's "The Old Man and the Sea." Hasanuddin University. Makassar.

Priadi, Arum. (2014). The analysis of Ellipsis within the Jakarta Post Cartoon: A Case Study. http://journal.uad.ac.id/index.php/adjes/article/view/1688/1184

Quirk, Randolph, et al. (1985). A Comprehensive Grammar of the English Language. London: Longman.

Suratni. (2006). Ellipsis as a Cohesive Device in English Printed Media Advertisement. http://library.gunadarma.ac.id/abstraction 10602167-skripsi fs.pdf

Swam, Michael. (1996). Practical English Usage. New Edition. Oxford: Oxford University Press.

Tarigan, Henry Guntur. (1986). Pengajaran Sintaksis. Bandung: Angkasa.

Thomson, A.J and Martinet, A.V. (1960). A Practical English Grammar. Fourth Edition. Hongkong: Oxford University Press.

William, Collin. (1990). Collins Cobuild English Grammar. London: The University Of Brimingham.

Woods, Geraldine. (2010). English Grammar for Dummies. Indiana: Wiley Publishing, Inc.

Yulianti, Lina. (2009). Ellipsis in Indonesian Printed Media Headlines. http://library.gunadarma.ac.id/abstraction 10602167-skripsi fs.pdf 